\title{
Synthesis of $p$-tert-Butylthiacalix[4]arenes Functionalized with Tris(2-aminoethyl)amine Fragments at the Lower Rim and Their Interaction with Model Lipid Membranes
}

\author{
Joshua B. Puplampu, ${ }^{a}$ Luidmila S. Yakimova, ${ }^{a}$ Alena A. Vavilova, ${ }^{a}$ \\ Dzhigangir A. Fayzullin, ${ }^{b}$ Yuriy F. Zuev, ${ }^{b}$ and Ivan I. Stoikova,b@ \\ ${ }^{a}$ Kazan Federal University, A.M. Butlerov Chemical Institute, 420008 Kazan, Russian Federation \\ ${ }^{\mathrm{b}}$ Kazan Institute of Biochemistry and Biophysics, Russian Academy of Sciences, 420111 Kazan, Russian Federation \\ ${ }^{\circledR}$ Corresponding authorE-mail: ivan.stoikov@mail.ru
}

\begin{abstract}
New tetrasubstituted derivatives of thiacalix[4]arene functionalized with tris(2-aminoethyl)amine fragments at the lower rim in the cone, partial cone and 1,3-alternate conformations have been synthesized. It has been shown that during the interaction of tris(2-aminoethyl)amine with thiacalix[4]arenes in cone and partial cone conformation, the cyclic fragments are formed. The structure with acyclic fragments is obtained in the case of thiacalix[4]arenes in 1,3alternate conformation. The interaction of these compounds with a biomembrane model system was studied. It has been shown that the interaction of these compounds with model lipid membranes depends not only on the presence of hydrophilic-hydrophobic groups but also on the spatial orientation of these groups.
\end{abstract}

Keywords: Thiacalix[4]arenes, liposomes, membranes, molecular recognition.

\section{Синтез n-mpem-бутилтиакаликс[4]аренов, функционализированных по нижнему ободу фрагментами трис(2-аминоэтил)амина, и их взаимодействие с модельными липидными мембранами}

\author{
А. Б. Пуплампу, ${ }^{\mathrm{a}}$ ᄉ. С. Якимова, ${ }^{a}$ А. А. Вавилова, ${ }^{\mathrm{a}}$ А. А. Файзуллин,, ${ }^{\mathrm{b}}$ Ю. Ф. Зуев, ${ }^{\mathrm{b}}$ \\ И. И. Стойков ${ }^{\mathrm{a}, \mathrm{b} @}$ \\ ${ }^{a}$ Казанский (Приволжский) федеральный университет, Химический институт им. А.М. Бутлерова, 420008 Казань, \\ Россия \\ ${ }^{\mathrm{b}}$ Казанский институт биохимии и биофизики, Российская Академия Наук, 420111 Казань, Россия \\ ${ }^{\circledR}$ E-mail: ivan.stoikov@mail.ru
}

\begin{abstract}
Синтезированы новые тетразамещенные производные тиакаликс[4]арена, функционализированные по нижнему ободу фрагментами трис(2-аминоэтил)амина, в конфигурациях конус, частичньй конус, 1,3-альтернат. Показано, что трис(2-аминоэтил)амин при взаимодействии с конфигурационными изомерами тиакаликс[4] арена склонен образовывать ичиклические фрагменты в случае конуса и частичного конуса и ациклические заместители - в случае 1,3-альтерната. Изучено взаимодействие полученных соединений с модельными биомембранами. Показано, что взаимодействие этих соединений с модельными липидными мембранами зависит не только от наличия гидрофильно-гидрофобных групп, но и от их пространственного расположения.
\end{abstract}

Ключевые слова: Тиакаликс[4]арены, липосомы, мембраны, молекулярное распознавание. 


\section{Introduction}

Polyamines are widely used in the development of vectors, drug delivery systems, therapeutics, diagnostic probes and nano-materials because they tend to selectively interact, transport and target deliver their cargo - nucleic acids, peptides, phospholipids. Molecules containing polyamines and guanidinium residues have been shown to interact effectively with cell membranes as well as facilitate the transport of cargo across membranes. ${ }^{[1-5]}$ They mostly achieve this by interacting with the phospholipid head groups.

It has been demonstrated that synthetic receptors bearing amide and sulfonamide derivatives of tris(2aminoethyl)amine (TREN) facilitate phospholipid flipflop across membranes. ${ }^{[6]}$ Moreover, they can promote the transmembrane diffusion of cargo in either direction. Also, tripodal receptors based on a TREN scaffold have been reported to bind nucleotides. ${ }^{[7]}$ Furthermore, natural polyamines $^{[8]}$ as well as synthetic macrocyclic polyamine receptors ${ }^{[9-13]}$ have been shown to effectively and selectively bind nucleotides with some forming supramolecular nanostructures while others successfully transfected cells. ${ }^{[14-16]}$ It is obvious that the TREN fragment, a potential receptor unit with several amino groups, takes part in such molecular recognition processes.

A number of synthetic macrocyclic platforms (e.g., crown ethers, cyclodextrins and calixarenes) have been used in the development of molecular receptors. ${ }^{[17-25]}$ Thiacalix[4] arenes, analogues of classical calixarenes, are unique in that the initial macrocycles are easily obtained by a onestep synthesis, ${ }^{[18,25]}$ their sulfide bridge fragments easily coordinates transition metal cations, ${ }^{[16]}$ whiles the upper and lower rims are easily functionalized. ${ }^{[18,25]}$ In addition, they exist in variable conformations ${ }^{[19-21]}$ hence they offer different spatial arrangement of functional groups, a prerequisite for molecular recognition. Previously, it was shown that $p$-tert-butylthiacalix[4]arenes functionalized by $N$-propyl morpholine, $N, N$-dipropyliden-amine and aminodiacetate fragments interacted with the polar domains of model lipid membranes. ${ }^{[26]}$ Therefore, we hypothesize that functionalizing the thiacalix[4]arene molecular platform with TREN fragments will not only produce effective receptors for the molecular recognition of DNA but are likely to result in efficient vectors which can easily cross the membrane barrier.

In this study, we describe the synthesis of p-tertbutylthiacalix[4]arenes functionalized with TREN fragments in the lower rim in the cone, partial cone and 1,3-alternate conformations and their interaction with model lipid membranes.

\section{Experimental}

\section{General}

The ${ }^{1} \mathrm{H}$ and ${ }^{13} \mathrm{C}$ NMR spectra were recorded on a Bruker Avance-400 (400 MHz) spectrometer. Chemical shifts were determined relative to the signals of residual protons of the deuterated solvent $\left(\mathrm{CDCl}_{3}\right)$. The concentration of sample solutions was $3-5 \%$
Most chemicals were purchased from Aldrich and used as received without additional purification. Organic solvents were purified by standard procedures.

IR spectra (nujol) were recorded with Vector 22 (Bruker) IR spectrometer.

Elemental analysis was performed with Perkin Elmer 2400 Series II instrument.

Mass spectra were recorded with the MALDI-TOF Dynamo Finnigan (using 2,5-dihydroxybenzoic acid and p-nitroaniline matrices).

Melting points were determined using the Boetius Block apparatus.

Additional control of purity of the compounds and monitoring of the reaction was carried out by thin-layer chromatography using Silica G, $200 \mu \mathrm{m}$ plates, UV 254.

Tetraesters 1-3 of p-tert-butylthiacalix[4]arenes in cone, partial cone and 1,3-alternate conformations respectively ${ }^{[27]}$ and tris(2-aminoethyl)amine were used as the initial reagents.

\section{Determination of Phase Transition Temperatures of DPPC Liposomes}

The liposomes were prepared by dissolving $26 \mathrm{mg}(0.035$ $\mathrm{mmol}$ ) of DPPC in $0.5 \mathrm{ml}$ of chloroform. The solvent was gently evaporated to obtain a thin film of lipid. The lipid was hydrated using $0.5 \mathrm{ml}$ of aqueous buffer $(20 \mathrm{mM}$ tris(hydroxymethyl)aminomethane, $\mathrm{HCl}, 150 \mathrm{mM} \mathrm{NaCl}, \mathrm{pH}=7.4$ ) with constant shaking for an hour at $50{ }^{\circ} \mathrm{C}$ to obtain a crude lipid suspension. Unilamellar liposomes of DPPC were prepared by extrusion of the hydrated lipid suspension using Avanti Mini-Extruder fitted with a $100 \mathrm{~nm}$ diameter pore size polycarbonate filter.

Stock solutions $(0.7 \mathrm{mM})$ of compounds were prepared by initially dissolving the corresponding mass of compound 4-6 in $200 \mathrm{~mL}$ of $2 \mathrm{M} \mathrm{HCl}$ solution and adjusting the final volume to $5 \mathrm{ml}$ with buffer. Samples were then prepared by adding the corresponding volume of compound 4-6 to lipid suspension $(0.7 \mathrm{mM})$ to obtain the desired ratio, and then the final volume adjusted to $3 \mathrm{ml}$ with buffer.

The lipid phase transition temperature was determined by measuring the turbidity of lipid suspensions $(0.7 \mathrm{mM})$ at $400 \mathrm{~nm}$ wavelength using the Shimadzu UV-3600 spectrophotometer. Titration of lipid suspensions with corresponding volumes of the studied compounds 4-6 was carried out in quartz cells with $10 \mathrm{~mm}$ optical path. The $\mathrm{T}_{\mathrm{m}}$ of lipid was determined by measuring the absorbance of samples at an interval of $0.3{ }^{\circ} \mathrm{C}$ within the temperature range 38 to $44^{\circ} \mathrm{C}$. Samples were thermostated for 3 minutes before each measurement using the Shimadzu TCC-240A temperature controlled cell holder. Thus, the average heating rate was $0.1{ }^{\circ} \mathrm{C} / \mathrm{min}$. The obtained relationship between absorbance and temperature were subjected to mathematical treatments resulting in $T_{m}$ values for various mole ratios of studied compounds and the lipid. Three independent titrations were carried out for each sample.

\section{Synthesis}

General Procedure for the Synthesis of Compounds 4, 5. To a mixture of p-tert-butylthacalix[4]arene 1 or $2(0.50 \mathrm{~g}$, $0.47 \mathrm{mmol}$ ) in a round bottom flask, $30 \mathrm{ml}$ of a mixture of toluene and methanol $(1: 1)$ was added, followed by $1.41 \mathrm{ml}(9.39 \mathrm{mmol})$ of tris(2-aminoethyl)amine. The reaction mixture was stirred under argon for 5 days at $60^{\circ} \mathrm{C}$. The solvent was removed under reduced pressure followed by the addition of $30 \mathrm{ml}$ of water to precipitate the product. The precipitate was filtered, washed with water then dried under reduced pressure over sodium hydroxide.

5,11,17,23-Tetra-tert-butyl-(25,26), (27,28)-di(bis [ $(a, b, c, d$ (3'-[N,N'-(2-aminoethyl) diethylenetriaminoamido)biscrown])2,8,14,20-tetrathiacalix[4]arene or Doubly amide-bridged p-tert-butylthiacalix[4]arene (cone-4). White powder, yield: 
0.53 g $(87 \%)$. Mp: $241{ }^{\circ} \mathrm{C} .{ }^{1} \mathrm{H}$ NMR $\left(\mathrm{CDCl}_{3}\right) \delta_{\mathrm{H}} \mathrm{ppm}(\mathrm{J} / \mathrm{Hz})$ : $1.11\left(\mathrm{~s}, 36 \mathrm{H},\left(\mathrm{CH}_{3}\right)_{3} \mathrm{C}\right), 2.57\left(4 \mathrm{H}, \mathrm{m}, \mathrm{NCH}_{2} \mathrm{CH}_{2} \mathrm{NH}_{2}\right), 2.67(8 \mathrm{H}$, $\left.\mathrm{m}, \mathrm{NHCH}_{2} \mathrm{CH}_{2} \mathrm{~N}\right), 2.72-2.78\left(8 \mathrm{H}, \mathrm{m}, \mathrm{NHCH}_{2} \mathrm{CH}_{2} \mathrm{~N}\right), 3.35-3.45$ $\left(8 \mathrm{H}, \mathrm{m}, \mathrm{NCH}_{2} \mathrm{CH}_{2} \mathrm{NH}_{2}\right), 4.61\left(4 \mathrm{H}, \mathrm{d}\right.$ AB-system, ${ }^{2} \mathrm{~J}_{\mathrm{HH}}=15.2 \mathrm{~Hz}$, $\left.-\mathrm{OCH}_{2} \mathrm{C}(\mathrm{O}) \mathrm{NH}\right), 5.20\left(4 \mathrm{H}, \mathrm{d}\right.$ AB-system, $\left.{ }^{2} \mathrm{~J}_{\mathrm{HH}}=15.2 \mathrm{~Hz},-\mathrm{OCH} \mathrm{C}_{2} \mathrm{O}\right)$ $\mathrm{NH}), 7.32\left(4 \mathrm{H}, \mathrm{d}\right.$ AB-system, $\left.{ }^{4} \mathrm{~J}_{\mathrm{HH}}=2.2 \mathrm{~Hz}, \mathrm{ArH}\right), 7.40(4 \mathrm{H}, \mathrm{d}$ ABsystem, $\left.{ }^{4} J_{\mathrm{HH}}=2.2 \mathrm{~Hz}, \mathrm{ArH}\right), 8.22\left(4 \mathrm{H}, \mathrm{t},{ }^{3} \mathrm{~J}_{\mathrm{HH}}=5.8 \mathrm{~Hz},-\mathrm{C}(\mathrm{O}) N H\right)$. ${ }^{13} \mathrm{C} \mathrm{NMR}\left(\mathrm{CDCl}_{3}\right) \delta_{\mathrm{C}} \mathrm{ppm}: 168.59,157.63,147.43,136.06,134.27$, $128.03,127.05,74.75,58.33,54.26,39.71,38.33,34.27,31.09$. MALDI-TOF MS: calculated $\left[\mathrm{M}^{+}\right] \mathrm{m} / z=1172.5$, found $[\mathrm{M}+\mathrm{H}]^{+}$ $m / z=1173.1,[\mathrm{M}+\mathrm{Na}]^{+} m / z=1195.0$. Found: $\mathrm{C}, 61.63 ; \mathrm{H}, 7.51 ; \mathrm{N}$, 9.98; S, $10.31 \%$. Calculated for $\mathrm{C}_{60} \mathrm{H}_{84} \mathrm{~N}_{8} \mathrm{O}_{8} \mathrm{~S}_{4}: \mathrm{C}, 61.40 ; \mathrm{H}, 7.21$; N, $9.55 ; \mathrm{S}, 10.93 \%$.

5,11,17,23-Tetra-tert-butyl-25,28-bis [(N-(2 ', 2 '”-bis [2'aminoethyl] amino)ethyl)carbamoylmethoxy)]-26,27-bis[(a,b,c,d(3'-[N, $N$ '-(2-aminoethyl) diethylenetriaminoamido)biscrown]2,8,14,20-tetrathiacalix[4]arene (partial cone-5). White powder, yield: $0.51 \mathrm{~g}(83 \%)$. Mp: $145{ }^{\circ} \mathrm{C} .{ }^{1} \mathrm{H}$ NMR $\left(\mathrm{CDCl}_{3}\right) \delta_{\mathrm{H}} \mathrm{ppm}$ $(\mathrm{J} / \mathrm{Hz}): 0.97\left(9 \mathrm{H}, \mathrm{s},\left(\mathrm{CH}_{3}\right)_{3} \mathrm{C}\right), 1.13\left(9 \mathrm{H}, \mathrm{s},\left(\mathrm{CH}_{3}\right)_{3} \mathrm{C}\right), 1.30(9 \mathrm{H}$, s, $\left.\left(\mathrm{CH}_{3}\right)_{3} \mathrm{C}\right), 1.35\left(9 \mathrm{H}, \mathrm{s},\left(\mathrm{CH}_{3}\right)_{3} \mathrm{C}\right), 1.61$ (br.s, $\left.10 \mathrm{H},-\mathrm{CH}_{2} \mathrm{NH}_{2}\right)$, 2.45-3.50 (28H, m, $\left.-\mathrm{NHCH}_{2} \mathrm{CH}_{2} \mathrm{~N},-\mathrm{NCH}_{2} \mathrm{CH}_{2} \mathrm{NH}_{2}\right), 2.58(8 \mathrm{H}$, $\left.\mathrm{dt},{ }^{3} J_{\mathrm{HH}}=11.0 \mathrm{~Hz},{ }^{3} J_{\mathrm{HH}}=6.0 \mathrm{~Hz},-\mathrm{NHCH}_{2} \mathrm{CH}_{2} \mathrm{~N}\right), 3.53(1 \mathrm{H}, \mathrm{d}$ AX-system, $\left.{ }^{2} J_{\mathrm{HH}}=16.0 \mathrm{~Hz},-\mathrm{OCH}_{2} \mathrm{C}(\mathrm{O}) \mathrm{NH}\right), 3.98(1 \mathrm{H}, \mathrm{d}$ AXsystem, $\left.{ }^{2} J_{\mathrm{HH}}=15.0 \mathrm{~Hz},-\mathrm{OCH}_{2} \mathrm{C}(\mathrm{O}) \mathrm{NH}\right), 3.99(1 \mathrm{H}, \mathrm{d} \mathrm{AX}$-system, $\left.{ }^{2} J_{\mathrm{HH}}=14.3 \mathrm{~Hz},-\mathrm{OCH}_{2} \mathrm{C}(\mathrm{O}) \mathrm{NH}\right), 4.94\left(2 \mathrm{H}, \mathrm{s},-\mathrm{OCH}_{2} \mathrm{C}(\mathrm{O}) \mathrm{NH}\right)$, $5.14\left(1 \mathrm{H}, \mathrm{d}\right.$ AX-system, $\left.{ }^{2} \mathrm{~J}_{\mathrm{HH}}=14.3 \mathrm{~Hz},-\mathrm{OCH} \mathrm{C}(\mathrm{O}) \mathrm{NH}\right), 5.22(1 \mathrm{H}$, d AX-system, $\left.{ }^{2} J_{\mathrm{HH}}=15.0 \mathrm{~Hz},-\mathrm{OCH}_{2} \mathrm{C}(\mathrm{O}) \mathrm{NH}\right), 5.25(1 \mathrm{H}, \mathrm{d}$ AXsystem, $\left.{ }^{2} J_{\mathrm{HH}}=16.0 \mathrm{~Hz},-\mathrm{OCH}_{2} \mathrm{C}(\mathrm{O}) \mathrm{NH}\right), 6.84(1 \mathrm{H}, \mathrm{d} \mathrm{AX}$-system, $\left.{ }^{4} J_{\mathrm{HH}}=2.4 \mathrm{~Hz}, \mathrm{ArH}\right), 7.01\left(1 \mathrm{H}, \mathrm{t},{ }^{3} J_{\mathrm{HH}}=5.4 \mathrm{~Hz},-\mathrm{C}(\mathrm{O}) N H\right), 7.23(1 \mathrm{H}, \mathrm{d}$ AB-system, $\left.{ }^{4} J_{\mathrm{HH}}=2.4 \mathrm{~Hz}, \mathrm{ArH}\right), 7.46\left(1 \mathrm{H}, \mathrm{dAB}\right.$-system, ${ }^{4} \mathrm{~J}_{\mathrm{HH}}=2.4 \mathrm{~Hz}$, ArH), $7.60\left(1 \mathrm{H}, \mathrm{d} \mathrm{AX}\right.$-system, $\left.{ }^{4} J_{\mathrm{HH}}=2.4 \mathrm{~Hz}, \mathrm{ArH}\right), 7.61(1 \mathrm{H}, \mathrm{d}$ ABsystem, $\left.{ }^{4} J_{\mathrm{HH}}=2.5 \mathrm{~Hz}, \mathrm{ArH}\right), 7.68\left(1 \mathrm{H}, \mathrm{d} \mathrm{AB}\right.$-system, ${ }^{4} J_{\mathrm{HH}}=2.5 \mathrm{~Hz}$, $\mathrm{ArH}), 7.73\left(1 \mathrm{H}, \mathrm{d} \mathrm{AB}\right.$-system, $\left.{ }^{4} \mathrm{~J}_{\mathrm{HH}}=2.6 \mathrm{~Hz}, \mathrm{ArH}\right), 7.76(1 \mathrm{H}, \mathrm{d}$ ABsystem, $\left.{ }^{4} J_{\mathrm{HH}}=2.6 \mathrm{~Hz}, \mathrm{ArH}\right), 7.84\left(1 \mathrm{H}, \mathrm{t},{ }^{3} \mathrm{~J}_{\mathrm{HH}}=5.4 \mathrm{~Hz},-\mathrm{C}(\mathrm{O}) \mathrm{NH}\right), 8.08$ $\left(1 \mathrm{H}, \mathrm{t},{ }^{3} J_{\mathrm{HH}}=5.5 \mathrm{~Hz},-\mathrm{C}(\mathrm{O}) N H\right), 8.76\left(1 \mathrm{H}, \mathrm{t},{ }^{3} J_{\mathrm{HH}}=5.5 \mathrm{~Hz},-\mathrm{C}(\mathrm{O}) N H\right)$. ${ }^{13} \mathrm{C} \mathrm{NMR}\left(\mathrm{CDCl}_{3}\right) \delta_{\mathrm{C}}$ ppm: 168.9, 168.7, 168.4, 168.1, 159.4, 158.8, 155.9, 154.8, 147.9, 147.6, 146.7, 146.1, 137.2, 136.5, 135.6, 135.3, $135.2,133.9,133.5,132.9,128.9,128.3,127.0,126.7,126.5,125.9$, 125.8, 124.7, 73.7, 73.6, 73.4, 69.3, 57.6, 57.4, 53.9, 53.6, 52.3, 51.9, $40.1,40.0,39.2,37.8,37.7,36.9,36.6,34.4,34.3,34.1,31.3,31.1$, 31.05, 31.01. IR $v \mathrm{~cm}^{-1}: 3298(\mathrm{NH}), 1661,1573,1529(\mathrm{C}(\mathrm{O}) \mathrm{NH})$. MALDI-TOF MS: calculated $\left[\mathrm{M}^{+}\right] m / z=1318.7$, found $[\mathrm{M}+\mathrm{Na}]^{+}$ $\mathrm{m} / \mathrm{z}=1340.4$. Found: C, 59.86; H, 7.39; N, 12.83; S, $10.01 \%$. Calculated for $\mathrm{C}_{66} \mathrm{H}_{102} \mathrm{~N}_{12} \mathrm{O}_{8} \mathrm{~S}_{4}$ : C, 60.06; H, 7.79; N, 12.73; S, $9.72 \%$.

Procedure for the synthesis of compound 6. To a mixture of p-tert-butylthacalix[4]arene $3(0.50 \mathrm{~g}, 0.47 \mathrm{mmol})$ in a round bottom flask, $30 \mathrm{ml}$ of a mixture of toluene and methanol (3:1) was added, followed by $1.41 \mathrm{ml}(9.39 \mathrm{mmol})$ of tris (2-aminoethyl)amine. The reaction mixture was refluxed under argon for 72 hours. The solvent was removed under reduced pressure followed by the addition of $30 \mathrm{ml}$ of water to precipitate the product. The precipitate was filtered, washed with water then dried under reduced pressure over sodium hydroxide.

5,11,17,23-Tetra-tert-butyl-25,26,27,28-tetrakis-[(N-(2",2"'bis [2'-aminoethyl] amino)ethyl) carbamoylmethoxy)]-2, 8, 14,20tetrathiacalix[4]arene or Tetrathiacalix[4]arene(ethyleneamido)biscrown (1,3-alternate-6). White powder, yield: $0.62 \mathrm{~g}(98 \%)$. Mp: $118{ }^{\circ} \mathrm{C} .{ }^{1} \mathrm{H} \mathrm{NMR}\left(\mathrm{CDCl}_{3}\right) \delta_{\mathrm{H}} \mathrm{ppm}(\mathrm{J} / \mathrm{Hz}): 1.20\left(36 \mathrm{H}, \mathrm{s},\left(\mathrm{CH}_{3}\right)_{3} \mathrm{C}\right)$, $1.62\left(16 \mathrm{H}\right.$, br.s, $\left.-\mathrm{N}\left(\mathrm{CH}_{2} \mathrm{CH}_{2} \mathrm{NH}_{2}\right)_{2}\right), 2.52\left(16 \mathrm{H}\right.$, br.t, ${ }^{3} J_{\mathrm{HH}}=5.1 \mathrm{~Hz}$, $\left.-\mathrm{N}\left(\mathrm{CH}_{2} \mathrm{CH}_{2} \mathrm{NH}_{2}\right)_{2}\right), 2.63\left(8 \mathrm{H}\right.$, br.t, $\left.{ }^{3} \mathrm{~J}_{\mathrm{HH}}=6.3 \mathrm{~Hz},-\mathrm{NHCH}_{2} \mathrm{CH}_{2} \mathrm{~N}\right)$, $2.71\left(16 \mathrm{H}, \mathrm{m},-\mathrm{N}\left(\mathrm{CH}_{2} \mathrm{CH}_{2} \mathrm{NH}_{2}\right)_{2}\right), 3.34\left(8 \mathrm{H}, \mathrm{m},-\mathrm{C}(\mathrm{O}) \mathrm{NHCH}_{2}\right), 3.97$ $\left(8 \mathrm{H}, \mathrm{s}, \mathrm{OCH}_{2} \mathrm{C}(\mathrm{O}) \mathrm{NH}\right), 7.53(8 \mathrm{H}, \mathrm{s}, \mathrm{ArH}), 8.11\left(4 \mathrm{H}\right.$, br.t, ${ }^{3} \mathrm{~J}_{\mathrm{HH}}=5.0$ $\mathrm{Hz},-\mathrm{C}(\mathrm{O}) \mathrm{NH}) .{ }^{13} \mathrm{C} \mathrm{NMR}\left(\mathrm{CDCl}_{3}\right) \delta_{\mathrm{C}} \mathrm{ppm}: 168.19,156.89,147.31$, $133.58,127.33,71.35,57.63,53.51,39.95,37.51,34.29,31.12$. IR $v \mathrm{~cm}^{-1}: 3298(\mathrm{NH}), 1661,1573,1529(\mathrm{C}(\mathrm{O}) \mathrm{NH})$. MALDI-TOF MS: calculated $\left[\mathrm{M}^{+}\right] \mathrm{m} / z=1464.8$, found $[\mathrm{M}+\mathrm{H}]^{+} \mathrm{m} / z=1465.8,[\mathrm{M}+\mathrm{Na}]^{+}$ $m / z=1487.9$. Found: C, 57.62; H, 8.42; N, 16.05; S, 8.31. Calculated for $\mathrm{C}_{72} \mathrm{H}_{120} \mathrm{~N}_{16} \mathrm{O}_{8} \mathrm{~S}_{4}: \mathrm{C}, 58.98 ; \mathrm{H}, 8.25 ; \mathrm{N}, 15.29 ; \mathrm{S}, 8.75 \%$.

\section{Results and Discussion}

\section{Synthesis of Thiacalix[4]arenes}

Among the large number of macrocyclic objects in supramolecular chemistry calixarenes stand in unique place, due to their ability of selective complexation, molecular transport, catalysis and ability to be potential biomimetics and building blocks for synthesis of supramolecular architectures. ${ }^{[28-30]}$ Cup-like structure of calix[4]arenes presents a suitable molecular platform for constructing on their basis threedimensional structures with wide range of cavity sizes, differing in number and type of binding centers, spatial arrangement of binding groups and also offers a possibility of forming asymmetric cavities and varying balance between rigidity and flexibility of receptor. ${ }^{[31,32]}$ The current main objective is functionalizing the thiacalix[4]arene molecular platform with TREN fragments and their interaction with model lipid membranes.

Preliminary study of the reaction conditions for the aminolysis tetraesters $\mathbf{1 - 3}$ of $p$-tert-butylthiacalix[4]arenes in cone, partial cone and 1,3-alternate conformations with tris(2-aminoethyl)amine (TREN) showed that while the reaction of tetraesters in cone $\mathbf{1}$ and partial cone $\mathbf{2}$ proceeds under room temperature, the 1,3-alternate 3 proceeds only when refluxed. Again, while a solvent mixture of toluene and methanol (1:1) favored the reaction of compounds 1 and $\mathbf{2}$ with TREN, the reaction of compound $\mathbf{3}$ with TREN was much faster when the amount of toluene in the solvent mixture was increased (toluene-methanol 3:1). This is related to the solubility of the tetraesters in toluene: the cone and partial cone stereoisomers are soluble at room temperature while the 1,3-alternate is soluble only upon heating. Though methanol should favor the aminolysis reaction, increasing the volume of toluene enhanced the solubility of the 1,3alternate stereoisomer hence the observed reaction rate. The reaction was monitored by TLC. Aminolysis of tetraesters 1, $\mathbf{2}$ and $\mathbf{3}$ yielded compounds 4, 5 and $\mathbf{6}$ respectively (Scheme 1). In the course of the experiment, it was observed that the reaction of the tetraesters 1 with excess of the amine (with or without solvent) always resulted in a mixture of products.

The structure and composition of the new thiacalix[4] arene derivatives 4, 5 and $\mathbf{6}$ were characterized by NMR ${ }^{1} \mathrm{H}$, ${ }^{13} \mathrm{C}$, IR spectroscopy, mass spectrometry (MALDI-TOF) and elemental analysis.

The interaction of initial compounds $\mathbf{1 - 3}$ give three different products of reaction 4-6. In the case of compound 1 cone conformation two pairs of ester units react with two out of the three amino groups of TREN forming a two cyclic ring with one free residual amino group due to spatial close order of the ester units. In case of the compound $\mathbf{2}$ in partial cone conformation two ester units of $\mathbf{2}$ reacts with two out of the three amino groups of TREN forming a cyclic ring with one free residual amino group, while each of the other two residual esters of $\mathbf{2}$ reacts with an amino group on different TREN molecules leaving two free residual amino groups for each TREN molecule. The spatial distance of two ester units in 1,3-alternate conformation of $\mathbf{3}$ allows product $\mathbf{6}$ containing eight free residual amino groups for each TREN molecule to be obtained. The compound $\mathbf{6}$ does not contain cyclic ring with one free residual amino group. 
The chemical shifts, multiplicity and the integral intensity of the proton signals in ${ }^{1} \mathrm{H}$ NMR spectra of the compound 4-6 are in good agreement with the proposed structure of $p$-tertbutylthiacalix[4]arene 4-6.

In the ${ }^{1} \mathrm{H}$ NMR spectrum of the compound 4 (Figure 1), the signals of tert-butyl protons were observed as one singlet $(1.11 \mathrm{ppm})$. It confirms the formation of tetrasubstituted product. The oxymethylene protons were observed as AB- spin system (4.61 and $5.20 \mathrm{ppm}$ ) with a spin-spin interaction constant of $15.2 \mathrm{~Hz}$. The signals of the aromatic protons of the macrocycle 4 were observed as two doublets of AB-spin system (7.32 and $7.40 \mathrm{ppm})$ with a spin-spin interaction constant of $2.2 \mathrm{~Hz}$. The signals of amide protons gave broadened triplet in a weak field at $8.22 \mathrm{ppm}$ with a spinspin interaction constant ${ }^{3} \mathrm{~J}_{\mathrm{HH}}=5.8 \mathrm{~Hz}$. The protons of each methylene group in - $\mathrm{NCH}_{2} \mathrm{CH}_{2} \mathrm{NH}_{2}$ fragment gave multiplets<smiles>CCOC(=O)COC(=O)COc1c(OCC(=O)OCC)cc(C(C)(C)C)cc1C(C)(C)C</smiles>

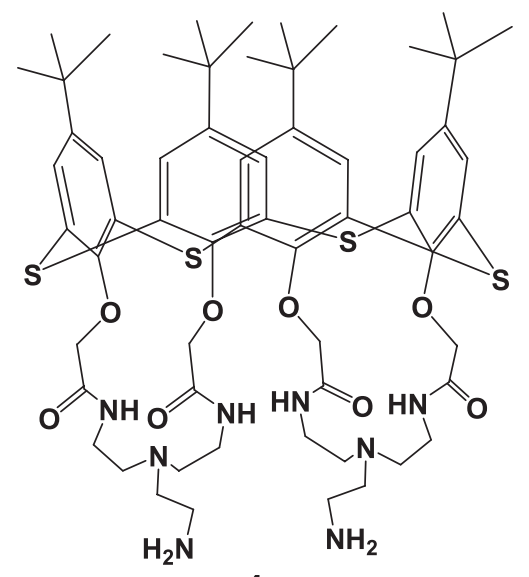

4

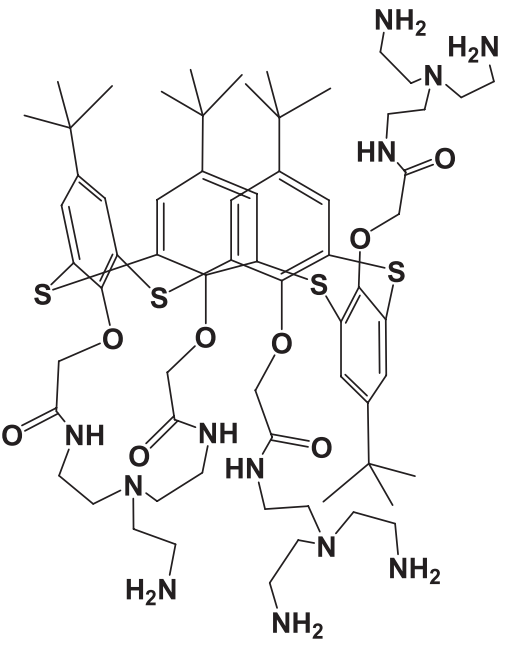

5

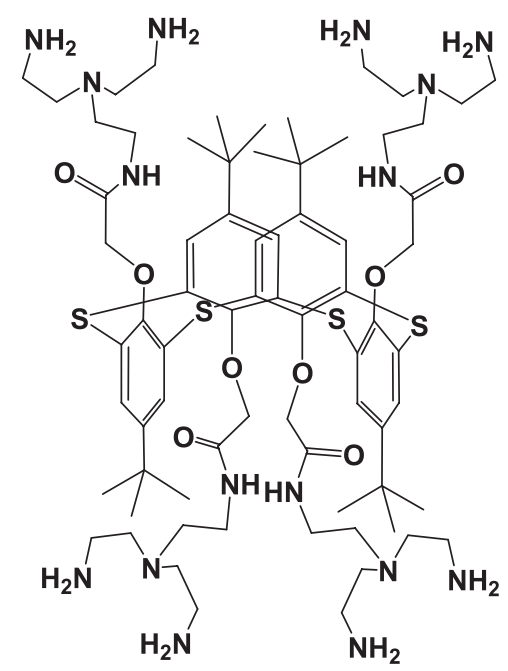

6

Scheme 1. Reagents and conditions: i, ii - TREN, toluene:MeOH (1:1); iii - TREN, toluene:MeOH (3:1), reflux. 
in a field at 2.57 and $3.35-3.45 \mathrm{ppm}$ correspondingly. The methylene protons of the $-\mathrm{NHCH}_{2}$ and $-\mathrm{CH}_{2} \mathrm{~N}$ fragments were observed as multiplets in a field 2.72-2.78 and $2.67 \mathrm{ppm}$ correspondingly. These characteristics in addition to the MALDI-TOF mass data $\left(\mathrm{m} / \mathrm{z}[\mathrm{M}+\mathrm{H}]^{+}=1173.1\right.$, $\left.[\mathrm{M}+\mathrm{Na}]^{+}=1195.0\right)$ made it possible to assign the structure of compound 4. Two out of the four ester groups have each been aminolysed by a TREN molecule with each TREN molecule having a residual amino group.

In the ${ }^{1} \mathrm{H}$ NMR spectrum of the compound 6 (Figure 1), the signals of tert-butyl, oxymethylene and aromatic protons were observed as one singlet at 1.20, 3.97 and $7.53 \mathrm{ppm}$ correspondingly. The signals of amide protons gave broadened triplet in a weak field at 8.11 with a spin-spin interaction constant ${ }^{3} J_{\mathrm{HH}}=5.0 \mathrm{~Hz}$. The amine protons are broadened singlet at $1.62 \mathrm{ppm}$. The protons of each methylene group in $-\mathrm{NCH}_{2} \mathrm{CH}_{2} \mathrm{NH}_{2}$ fragment gave broadened triplet and multiplet in a field at 2.52 and $2.71 \mathrm{ppm}$ correspondingly. The methylene protons of the $-\mathrm{NHCH}_{2}-$ and $-\mathrm{CH}_{2} \mathrm{~N}$ fragments were observed as multiplet (3.34 ppm) and broadened triplet in a field at $2.63 \mathrm{ppm}$ with a spin-spin interaction constant ${ }^{3} J_{\mathrm{HH}}=6.3 \mathrm{~Hz}$ correspondingly.

As an example, the MALDI-TOF mass spectrum of the tetrasubstituted at the lower rim $p$-tert-butylthiacalix[4]arene 5 is shown in Figure 3. The compound in which all the four ethyl esters have successfully undergone aminolysis by three tris(2-aminoethyl)amine molecules can be identified $(\mathrm{m} / \mathrm{z}$ $\left.[\mathrm{M}+\mathrm{H}]^{+}=1318.8\right)$. Two ester units of 1 reacts with two out of the three amino groups of TREN forming a cyclic ring with one free residual amino group, while each of the other two residual esters of $\mathbf{1}$ reacts with an amino group on different TREN molecules leaving two free residual amino groups for each TREN molecule. In the MALDI-TOF mass spectrum of the compound $\mathbf{6}$ the peaks of the molecular ion with sodium cation $\left(m / z[\mathrm{M}+\mathrm{Na}]^{+}=1340.4\right)$ are presented.

${ }^{1} \mathrm{H}$ NMR spectrum of the compound 5 has more difficult character because contain four nonequivalent aromatic rings, which is exhibited in the definite region in ${ }^{1} \mathrm{H}$ NMR spectrum.

During the interaction of two multifunctional reagents (tetraesters 1-3 and TREN) under conditions of oligoamine excess, the expected target product containing eight primary amino groups is formed only in case of the 1,3-alternate conformation. On the contrary, the cyclic products are formed in case of the cone and partial cone conformations. It is not characteristic for diethylenetriamine. ${ }^{[33]}$ Such fact is obviously caused by a complementary of the reactionary centers of TREN amino groups and ester fragments of tetraester 1-3.

Thus, new tetrasubstituted derivatives of thiacalix[4] arene functionalized with TREN fragments in the lower rim in the cone, partial cone and 1,3-alternate conformations 4-6 have been synthesized. The structure of the obtained compounds was characterized by ${ }^{1} \mathrm{H}$ NMR, ${ }^{13} \mathrm{C}$, IR spectroscopy and mass spectrometry (MALDI-TOF).

\section{The Effect of Compounds 4-6 on Model Lipid Membranes}

The interaction of compounds 4-6 with a biomembrane model system was studied. The lipid membranes were made up of unilamellar dipalmitoylphosphatidylcholine (DPPC) liposomes with a diameter of $100 \mathrm{~nm}$. The phase transition temperature was determined by the change in turbidity of lipid suspension using the Shimadzu UV-3600 spectrophotometer at a wavelength of $400 \mathrm{~nm} \cdot{ }^{[34]}$ Depending on the change in phase transition temperature, the degree of interaction between the membrane and a compound can be assessed. From Table 1 it is apparent that at a molar ratio of 1:100 (compound:DPPC), a slight increase in the $T_{m}$ of the DPPC liposomes in the presence of compounds $\mathbf{4}$ and $\mathbf{5}$ is observed as against in the presence of compound $\mathbf{6}\left(41.2 \pm 0.1{ }^{\circ} \mathrm{C}\right)$ which virtually had no significant effect on the $\mathrm{T}_{\mathrm{m}}$ of DPPC liposomes. It is known that small amphiphilic molecules are often located in the headgroup domain of lipid membranes. ${ }^{[35-39]}$ Moreover, amphiphilic calixarenes have been shown to be embedded in lipid membranes. ${ }^{[40-43]}$

Table 1. Phase transition temperatures of mixtures of compounds 4-6 and DPPC.

\begin{tabular}{cccc}
\hline $\begin{array}{c}\text { Molar ratio } \\
\text { Compound : DPPC }\end{array}$ & $\mathbf{4}:$ DPPC & $\mathbf{5 : \text { DPPC }}$ & $\mathbf{6}:$ DPPC \\
\hline $0: 1$ & $41.0 \pm 0.2$ & $41.0 \pm 0.2$ & $41.0 \pm 0.2$ \\
$1: 100$ & $41.4 \pm 0.1$ & $41.4 \pm 0.1$ & $41.2 \pm 0.1$ \\
$1: 75$ & $41.8 \pm 0.2$ & - & $41.5 \pm 0.1$ \\
$1: 50$ & - & - & $41.7 \pm 0.1$ \\
\hline
\end{tabular}

Thus, we can assume that compounds $\mathbf{4}$ and $\mathbf{5}$ which have distinct hydrophilic and hydrophobic domains are located close to phospholipid phosphate headgroups with their protonated $\mathrm{NH}_{3}{ }^{+}$groups forming ion-pairs with the phosphate headgroups in addition to hydrogen bonding between $\mathrm{P}=\mathrm{O} \cdots \mathrm{H}-\mathrm{N}$ groups. The lipophilic region is embedded and interacts with the lipid hydrophobic region of the membrane. These interactions resulted in the slight increase in $\mathrm{T}_{\mathrm{m}}$. While a further increase in molar concentration (1:75) of compounds corresponded to an increase in $\mathrm{T}_{\mathrm{m}}$, total solubilization of the liposomes is only observed for compound $\mathbf{5}$ at this concentration. It is possible that in an attempt by the hydrophobic region of $\mathbf{5}$ to dissolve deep and interact with the hydrophobic membrane core, the hydrophilic region gradually sinks just below the phosphate headgroups resulting in the disorganization of liposome structure due to the nonsymmetrical spatial orientation of the hydrophilic groups of $\mathbf{5}$. Thus, a slight increase in the molar concentration of $\mathbf{5}$ resulted in the solubilization of the liposome. Solubilization of the liposome membrane by 4 occurred only above a molar ratio of 1:75 (4:DPPC).

Although compounds $\mathbf{4}$ and $\mathbf{6}$ are symmetrical, the distinct hydrophobic core of compound $\mathbf{6}$ which is shielded by the hydrophilic groups unlike in $\mathbf{4}$ and $\mathbf{5}$ is unavailable for interaction with the hydrophobic tails of lipid membranes. Only the hydrophilic regions effectively interact with the phosphate headgroups. The hydrophobic core of compound 6 hardly gets access to the lipophilic region of the membrane. Solubilization in this case only occurs after a molar ratio of 1:50 (Figure 4). Obviously, solubilization of the liposome membrane is affected by not only hydrophilic-hydrophobic interactions but also the spatial orientation of such groups in the compounds. 


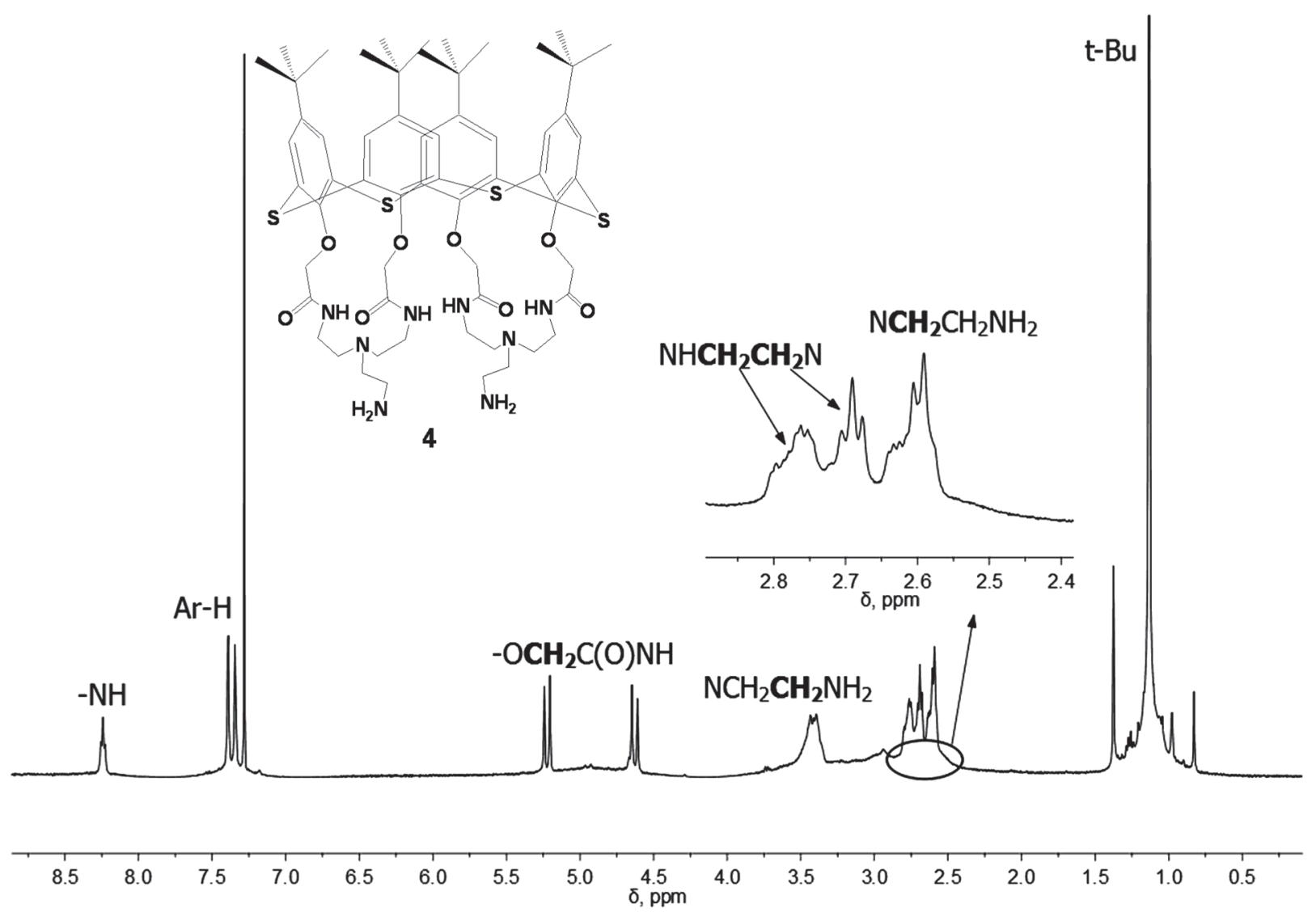

Figure 1. ${ }^{1} \mathrm{H}$ NMR spectrum of compound $4\left(\mathrm{CDCl}_{3}\right.$, at $25^{\circ} \mathrm{C}$, Bruker Avance-400).

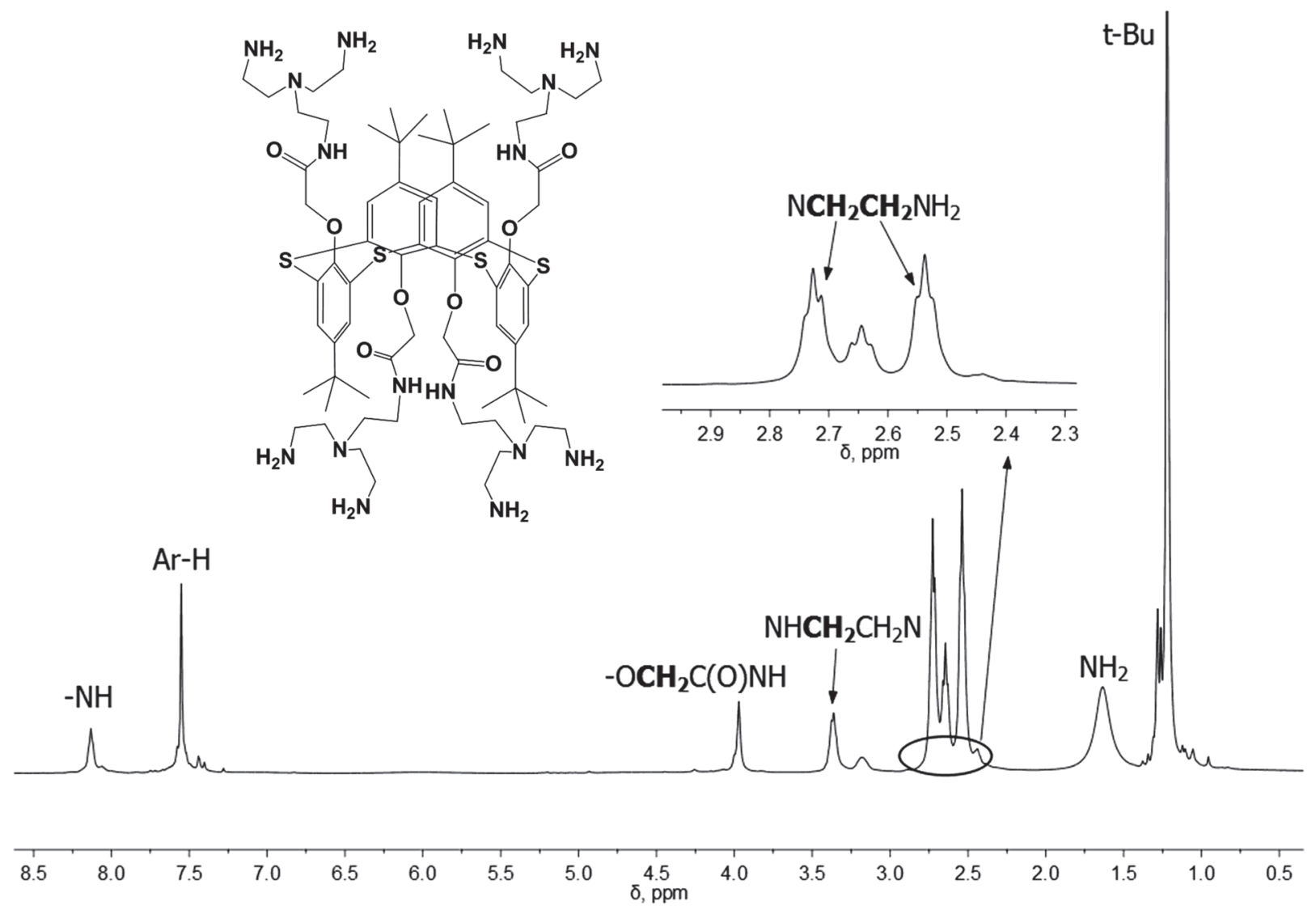

Figure 2. ${ }^{1} \mathrm{H}$ NMR spectrum of compound $6\left(\mathrm{CDCl}_{3}\right.$, at $25^{\circ} \mathrm{C}$, Bruker Avance-400). 


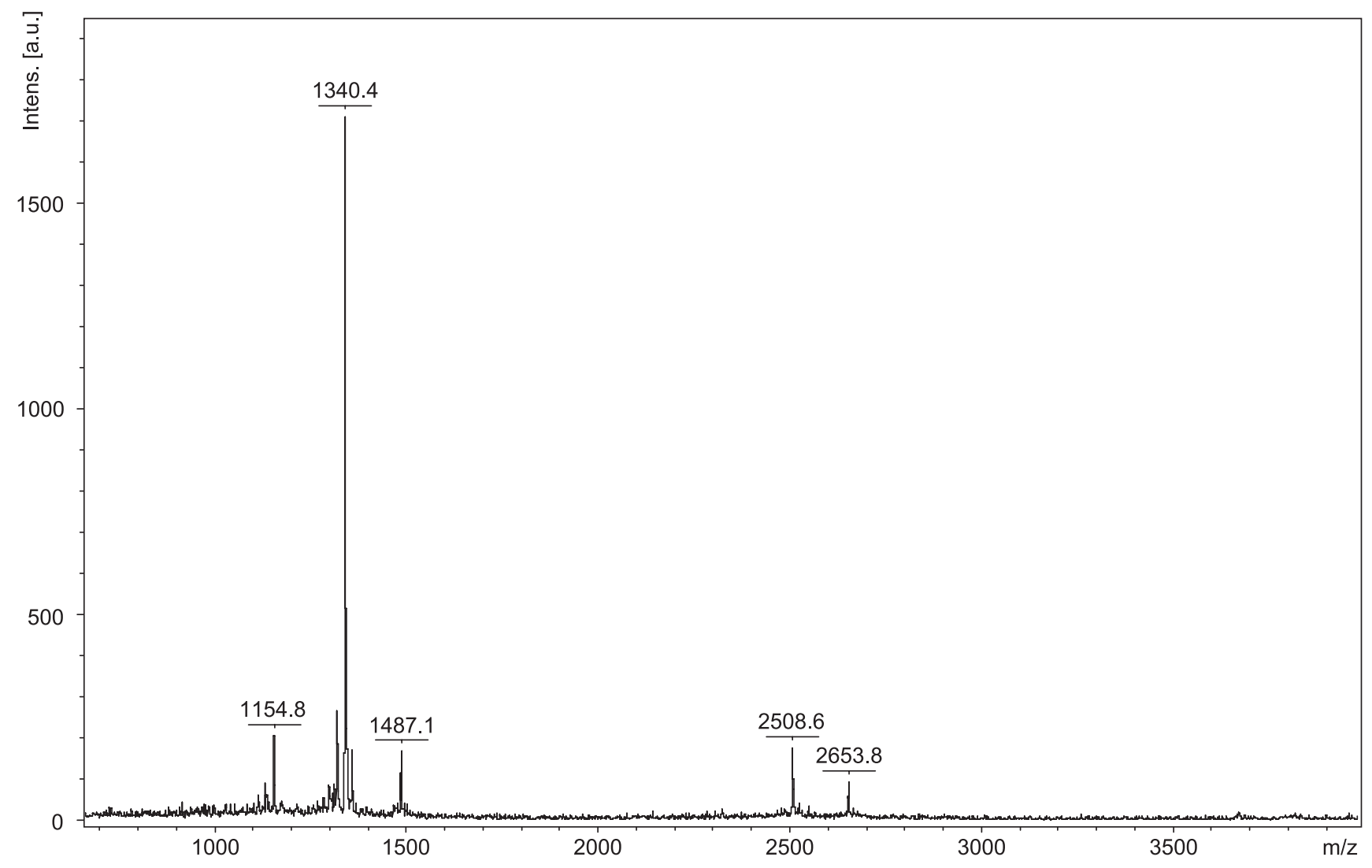

Figure 3. MALDI-TOF mass-spectrum of compound 5.

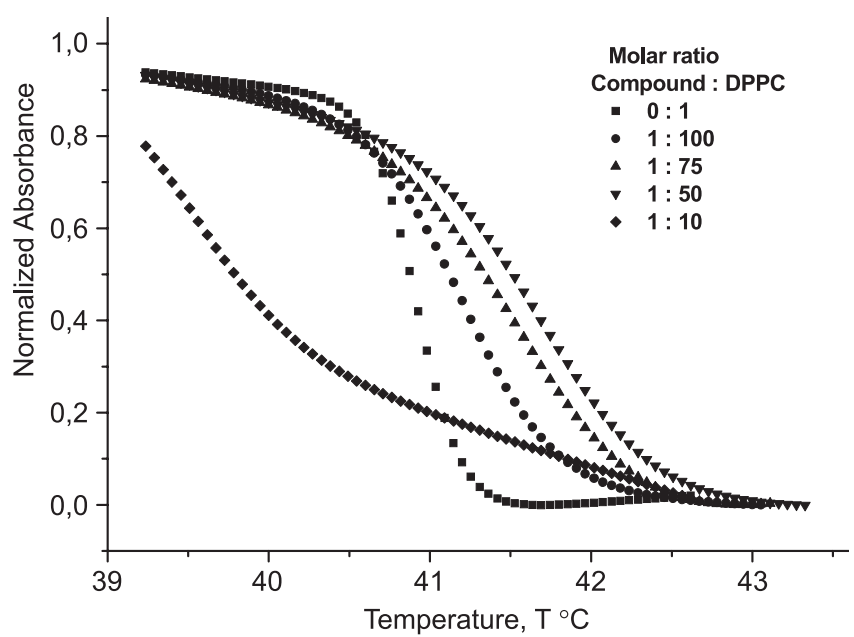

Figure. 4. A spectrophotometric titration of compound 6 (7, 9.3, 14 and $70 \mu \mathrm{M}$ ) against $0.7 \mathrm{mM}$ of DPPC liposomes at $400 \mathrm{~nm}$.

\section{Conclusion}

Thus, new tetrasubstituted derivatives of thiacalix[4] arene functionalized with TREN fragments in the lower rim in the cone, partial cone and 1,3-alternate conformations 4-6 have been synthesized. During the interaction of two multifunctional reagents (tetraesters 1-3 and TREN) under conditions of oligoamine excess, the expected target product containing eight primary amino groups is formed only in case of the 1,3-alternate conformation. On the contrary, the cyclic products are formed in case of the cone and partial cone conformations. It has been shown that the interaction of these compounds with lipid membrane models depends not only on the presence of hydrophilic-hydrophobic groups but also on the spatial orientation of these groups.

Acknowledgements. The work was supported by the Russian Foundation for Basic Research (grant no. 12-03-000252-a, 12-03-01085-a).

\section{References}

1. Zhang L., Lee H-K., Pruess T.H., White H.S., Bulaj G.J. Med. Chem. 2009, 52, 1514-1517.

2. Walrant A., Bechara C., Alves I.D., Sagan S. Nanomedicine 2012, 7, 133-143.

3. Vive`s E., Brodin P., Lebleu B.A. J. Biol. Chem. 1997, 272, 16010-16017.

4. Torchilin V.P., Rammohan R., Weissig V., Levchenko T.S. Proc. Natl Acad. Sci. USA 2001, 98, 8786-8791.

5. Pantos A., Tsogas I., Paleos C.M. Biochim. Biophys. Acta, Biomembr. 2008, 1778, 811-823.

6. Boon J.M., Lambert T.N., Smith B.D., Beatty A.M., Ugrinova V., Brown S.N. J. Org. Chem. 2002, 67, 2168-2174.

7. Albelda M.T., García-Espana E., Jimenez H.R., Llinares J.M., Soriano C., Sornosa-Ten A., Verdejo B. Dalton Trans. 2006, 4474-4481.

8. Nakai C., Glinsmann W. Biochemistry 1977, 16, 5636-5641.

9. Galukhin A.V., Stoikov I.I. Mendeleev Commun. 2014, 24, 82-84.

10. Andreyko E.A., Padnya P.L., Daminova R.R., Stoikov I.I. RSC Advanced 2014, 4, 3556-3565.

11. Galukhin A.V., Shabalin K.V., Antipin I.S., Konovalov A.I., Stoikov I.I. Mendeleev Commun. 2013, 23, 41-43. 
12. Galukhin A.V., Zaikov E.N., Antipin I.S., Konovalov A.I., Stoikov I.I. Macroheterocycles 2012, 5, 266-274.

13. Mostovaya O.A., Agafonova M.N., Galukhin A.V., Khayrutdinov B.I., Islamov D., Kataeva O.N., Antipin I.S., Konovalov A.I., Stoikov I.I. J. Phys. Org. Chem. 2014, 27, 57-65.

14. Bagnacani V., Sansone F., Donofrio G., Baldini L., Casnati A., Ungaro R. Org. Lett. 2008, 10(18), 3953-3956.

15. Goun E.A., Pillow T.H., Jones L.R., Rothbard J.B., Wender P.A. ChemBioChem 2006, 7, 1497-1515.

16. Nishihara M., Perret F., Takeuchi T., Futaki S., Lazar A.N., Coleman A.W., Sakai N., Matile S. Org. Biomol. Chem. 2005, 3, 1659-1669.

17. Asfari Z., Böhmer V., Harrowfield J., Vicens J. Calixarenes 2001. Dordrecht: Kluwer Academic Publishers, 2001. 700 p.

18. Gutsche C.D. Calixarenes. - An Introduction. 2nd Edition. Cambridge: RSC, 2008. 280 p.

19. Iki N., Miyano S. J. Inclusion Phenom. Macrocycl. Chem. 2001, 41, 99-105.

20. Lhotak P. Eur. J. Org. Chem. 2004, 71, 1675-1692.

21. Morohashi N., Narumi F., Iki N., Hattori T., Miyano S. Chem. Rev. 2006, 106, 5291-5316.

22. Steed J.W., Atwood J.L. Supramolecular Chemistry. 2nd Edition. Weinheim: John Wiley Hoboken, 2009. 998 p.

23. Atwood J.L., Steed J.W. Organic Nanostructures. Wiley-VCH, Weinheim, 2008. 233 p.

24. Vicens J., Harrowfield J. Calixarenes in the Nanoworld. London: Springer, 2007. 395 p.

25. Gutsche C.D. Calixarenes Revisited. In Monographs in Supramolecular Chemistry. London: RSC, 1998. 233 p.

26. Faizullin D.A., Vylegzhanina N.N., Gnezdilov O.I., Salnikov V.V., Galukhin A.V., Stoikov I.I., Antipin I.S., Zuev Y.F. Appl. Magn. Reson. 2011, 40, 231-243.
27. Iki N., Narumi F., Fujimoto T., Morohashi N., Miyano S. J. Chem. Soc., Perkin Trans. 2 1998, 2745-2750.

28. Galukhin A.V., Andreyko E.A., Rizvanov I.H., Stoikov I.I. Mendeleev Commun. 2013, 23, 196-198.

29. Stoikov I.I., Yushkova E.A., Bukharaev A.A., Biziaev D.A., Selivanovskaya S.Yu., Chursina M.A., Antipin I.S., Konovalov A.I., Zharov I. J. Phys. Org. Chem. 2012, 25, 1177-1185.

30. Stoikov I.I., Vavilova A.A., Badaeva R.D., Gorbachuk V.V., Evtugyn V.G., Sitdikov R.R., Yakimova L.S., Zharov I. J. Nanopart. Res. 2013, 15, 1617-1631.

31. Vavilova A.A., Nosov R.V., Yakimova L.S., Antipin I.S., Stoikov I.I. Macroheterocycles 2013, 6, 219-226.

32. Vavilova A.A., Nosov R.V., Yagarmina A.N., Mostovaya O.A., Antipin I.S., Konovalov A.I., Stoikov I.I. Macroheterocycles 2012, 5, 396-403.

33. Chakrabarti A., Chawla H.M., Pant N., Singh S.P., Upreti S. Tetrahedron 2006, 62, 8974-8981.

34. Gaub H., Buschl R., Ringsdorf H., Sackmann E. Chem. Phys. Lipids 1985, 37, 19-43.

35. Barry J.A., Gawrisch K. Biochemistry 1994, 33, 8082-8088.

36. Feller S.E., Brown C.A., Gawrisch K. Biophys. J. 2002, 82, 1396-1404.

37. Holte L.L., Gawrisch K. Biochemistry 1997, 36, 4669-4674.

38. Rottenberg H. Biochemistry 1992, 31, 9473-9481.

39. Chiou J.-S., Krishna P.R., Kamaya H., Ueda I. Biochim. Biophys. Acta 1992, 1110, 225-233.

40. Schrader T. Nat. Chem. 2012, 4, 519-520.

41. Zadmard R., Arendt M., Schrader T. J. Am. Chem. Soc. 2004, 126, 7752-7753.

42. Zadmard R., Schrader T. J. Am. Chem. Soc. 2005, 127, 904915.

43. Costa P.J., Marques I., Félix V. Biochim. Biophys. Acta 2014, 1838, 890-901. 